\title{
From the Life to the Mind of the Writer in the Literary Biopic: Andrucha Waddington's Lope and Ray Loriga's Teresa
}

\author{
Julien Jacques Simon \\ Indiana University East \\ jjsimon@iu.edu
}

\begin{abstract}
Lope (Andrucha Waddington 2010) and Teresa (Ray Loriga 2007) have much in common. Both biopics center on a revered literary figure of the Spanish Golden Age. However, in spite of their many commonalities, these films embody two distinct tendencies in the contemporary literary biopic genre: one more "typical," represented by Lope, that focuses heavily on plot development and another, represented by Teresa, that aspires to visually transpose to the screen aspects that relate to the main character's interiority. Although Teresa has features of the "typical" contemporary literary biopic, it innovates the genre significantly by moving its focus from the life to the mind of the writer. Loriga uses the language of cinematography to depict the imagery and affective
\end{abstract}


qualities of the mysticism of Teresa de Ávila-the force behind her writings-, creating a film that emphasizes image and emotions over plot. Teresa thus brings a different sensitivity to the literary biopic, which deviates from more formulaic films. Centering on the author's mind can indeed be a new path for filmmakers to innovate the biopic genre, particularly in its literary strand. Finally, these two biopics illustrate the need to expand the scholarly conversation about the contemporary literary biopic genre, as they both engage with and deviate from the formula established by Anglo-Saxon biopics.

Keywords: Loriga; Waddington; Lope; Teresa of Avila; biopic; mind; film; Golden Age

\section{Resumen}

Lope (Andrucha Waddington 2010) y Teresa (Ray Loriga 2007) tienen mucho en común. Ambos biopics se centran en una figura literaria venerada de las letras españolas del Siglo de Oro. Sin embargo, a pesar de las muchas características que comparten, estas películas encarnan dos tendencias distintas en el género del biopic literario contemporáneo: una más "típica”, representada por Lope, que se centra fuertemente en el desarrollo de la trama y otra, representada por Teresa, que aspira a trasladar visualmente a la pantalla los aspectos que se relacionan con la interioridad del personaje principal. Aunque Teresa tiene rasgos del biopic literario contemporáneo "típico", innova significativamente el género al enfocarse en la mente del escritor más que en su vida. Loriga utiliza el lenguaje de la cinematografía para trasladar a la pantalla el imaginario y las cualidades afectivas del misticismo de Teresa de Ávila-la fuerza catalizadora de sus escritos-, creando así una película que enfatiza la imagen y las emociones por encima de la trama. Teresa aporta así una sensibilidad diferente al género del biopic literario, que se desvía de la fórmula más estándar. Centrarse en la mente del autor puede ser, en efecto, una nueva pauta para innovar el género del biopic, particularmente en su vertiente literaria. Finalmente, estas dos películas ilustran la necesidad de ampliar el discurso académico sobre el género del biopic literario contemporáneo, ya que adoptan y a la vez se desvían de la fórmula establecida por los biopics anglosajones. 
Palabras clave: Loriga; Waddington; Lope; Teresa de Ávila; biopic; mente; película; Siglo de Oro

\section{Lope, Teresa, and the Contemporary Literary Biopic}

Lope (Andrucha Waddington 2010) and Teresa (Ray Loriga 2007) have much in common. Both biopics center on a revered literary figure of the Spanish Golden Age: Playwright Lope de Vega (1562-1635) and writer Teresa de Ávila (1515-1582), respectively. In both biopics, the difficulties that they encounter constitute an important thread. Additionally, their stories begin right before they reach a pinnacle in their lives, when they are still becoming their most memorable selves, a feature that connects them to current international trends in the literary biopic. ${ }^{1}$ In this essay, I will show that in spite of their many commonalities these films embody two distinct tendencies in the contemporary literary biopic genre: one more "typical" represented by Lope that focuses heavily on plot development and another represented by Teresa that aspires to visually transpose to the screen aspects that relate to the main character's interiority. Although Teresa has features of the "typical" contemporary literary biopic (such as the abovementioned "becoming" trope or the hurdles encountered in life), it innovates the genre significantly by moving its focus from the life to the mind of the writer.

One of the main aspects of the contemporary literary biopic genre has been to create an "authoresque landscape"2 by weaving the authors' biography with their literary production. Shachar discussed this feature in relation to Becoming Jane (Julian Jarrod 2007) ${ }^{3}$ and we can see it in biopics such as Molière (Laurent Tirard 2007), Young Goethe in Love (Philipp Stölzl 2010) and Shakespeare in Love (John Madden 1998), among many others. This blending mainly occurs on a plot level: the stories of the fictional characters in the works written by these authors are used (sometimes verbatim) to tell the 
stories of the actual authors in the biopics, thus blurring the line between the literary adaptation and the biopic genre. ${ }^{4}$ However, in Teresa the blending of life and literature takes place on a more visual level. As we will see, Loriga uses the language of cinematography to transpose to the screen the imagery and affective qualities of the mysticism of Teresa de Ávila-the force behind her writings - creating a film that emphasizes image and mood over plot. Teresa thus brings a different sensitivity to the literary biopic, which deviates from more formulaic biopics such as the above-mentioned Shakespeare in Love, Becoming Jane, or Young Goethe in Love.

Before delving further into the subject, it is important to clarify that this essay will not discuss the biopics' politics/ideology ${ }^{5}$ or their financial/industryrelated aspects. ${ }^{6}$ It will be neither a discussion about the films' reception and their lackluster success at the box office ${ }^{7}$ nor a reflection on the intersection of commercial considerations and artistic decisions made by the directors and producers of these films; nor will it be an exploration of the historical "truth" of the two biopics (that is, whether they accurately portray the lives of these authors). ${ }^{8}$ My main focus here will be to compare and analyze these two films, Lope and Teresa, with the ultimate purpose of showing how Teresa innovates the literary biopic genre.

\section{Life: The "Becoming" Trope}

In Lope, the "becoming" trope constitutes the framing narrative. When the movie opens, Lope is a penniless soldier not necessarily inclined to the belles lettres, but eager to improve his situation in society. When it ends, he has established himself as a successful playwright, no longer struggling economically. He has become the Lope of the contemporary public's imagination: passionate, brilliant, and scandalous. Indeed, besides his tumultuous love life, Lope is remembered today as the master of poets, for the prolific nature of his dramatic output and for being the father of the modern 
stage. Lope is often referred to as "el Fénix de los ingenios" [the Phoenix of Wits] because of the verve and brilliance of his writing and Cervantes himself called him "el monstruo de naturaleza" (the monster of nature), alluding to the sheer number of literary texts he penned. ${ }^{9}$ Although about 400 of his plays have survived, ${ }^{10}$ there could be twice as many (Morley and Bruerton). And he is the author of numerous collections of poems as well as some works of prose. His Arte nuevo de hacer comedias (The New Art of Writing Plays 1609), in which he outlines the renovations and precepts that turned theatrical performances into a thriving art form and business, has left an indelible mark in the history of theater. It is this facet of Lope's life that Waddington chose to emphasize: Lope the poet and renovator- "in the making"-of the Spanish stage.

Saint Teresa of Ávila was arguably the most prominent female writer in sixteenth century Spain. She was also a nun, mystic, and Saint (she was beatified in 1614, canonized in 1622, and made a Doctor of the Church in 1970), who was a reformer of the Carmelite order and founded the order of Discalced Carmelite Nuns. In a comparative study of the three biographical films on Teresa de Ávila that exist up to this day (by Orduña in 1962, Molina in 1983, and Loriga in 2007), Celia Martín-Pérez identifies two phases in the representation of the development of Teresa: The first phase is her spiritual journey when she becomes a nun at age 19 until she founds the first convent. It is during this time period that she spiritually matures, refines her theological aspirations, and develops her own ideas regarding Church doctrines. The second phase is when she becomes a religious leader who will found the Order of Discalced Carmelites and subsequently several convents throughout the Peninsula. Loriga emphasizes the former phase and, as Martín-Pérez points out, his "film closes just when the first convent is established [and] skips over the rest of Teresa's untiring work as an organizer" (26). It is the phase of Teresa's life when she is in the making that interests Loriga, when Teresa is not yet the Saint that history favors. 


\section{Life: Fighting Resistance}

As George Custen has long noted in his seminal work, overcoming the resistance that the hero encounters in society or within his/her own family or circle of friends is a hallmark of the classical Hollywood biopic. ${ }^{11}$ It continues to be a frequent framing narrative of contemporary biopics, whether or not they focus on literary figures. For example, one can think of Wilde (Brian Gilbert 1997) on Oscar Wilde, who faced the ire (and justice) of his contemporaries because of his sexual orientation, or Howl (Rob Epstein and Jeffrey Friedman 2010) on Allen Ginsberg (Beat Generation), whose eponymous poem dedicated to Carl Solomon was deemed obscene. Both films include several trial scenes that symbolize society's rejection of who they were. Additionally, both in Becoming Colette (Danny Huston 1991) and Colette (Wash Westmoreland 2018) the eponymous protagonist has to eventually combat her husband to establish herself as a writer and a person. In Lope the resistance comes from the "theater establishment," represented by Don Jerónimo Velázquez (Juan Diego), the theater impresario who will eventually accept his new approach to theater, while in Teresa this resistance will come from the Church.

Lope's difficulties start off with his economic struggles, which are akin to those of his fellow compatriots: to survive in a society exhibiting stark inequalities. Although he is a soldier, Lope is broke. Upon his return from the Azores expedition, poorly groomed and dressed, he asks an old friend, a servant of the Marqués de las Navas (Selton Mello) to loan him some decent clothes to appear before his mother as a successful soldier. Then, he proudly shows her a purse supposedly full of golden coins, which turn out to be mere nails. When Lope's mother dies, he is unwilling to accept the dire financial situation of his family and worries about the "¿Qué dirán?" [What will the others think?].12 In order to offer the grandiose ceremony that his mother deserves, he takes out a loan from a shady moneylender. "La honra" [honor/ reputation], or the need "to keep up appearances," is a literary trope and 
a facet of early modern Spain that surfaces throughout the first part of the film. ${ }^{13}$ Lope's troubles will also begin as he attempts to get ahead in the world of theater. The first illustration of his troubles comes when Don Jerónimo Velázquez complains of Lope's "arreglos" (arrangements) to the play he had asked him to just "copy," to learn the ropes as he was just starting in this line of work (21:50). Lope's genius will become obvious to the viewer afterward, during the first performance of a play (Cervantes' El cerco de Numancia) that features his arreglos or new art/way of staging plays. The audience is smiling and engaged and instead of throwing vegetables at the actors, they applaud them with enthusiasm. Don Jerónimo Velázquez's initial skeptical response to Lope's novel ideas illustrates the resistance to his brilliance. When said resistance is overcome, the protagonist turns into an unquestionable genius. Each subsequent play written or arranged by Lope will be met with popular success, thus completing his hagiographic portrait.

Loriga's film contains a "dual plot" or two framing narratives: one about Teresa's "love" or passion for Christ and another about her struggles with the Church. Yolanda López López, for instance, in her study of this movie, describes these two plots as follows:

El personaje de Teresa se definirá mediante dos tramas: el primero, sus encuentros con Cristo, períodos de pasión, sensualidad que Loriga filma con un sentido visual casi onírico; y, por otro, el camino de perfección de Teresa hasta convencer a las autoridades eclesiásticas de que sus visiones místicas no provienen del diablo sino de Dios; la incomprensión de sus confesores y las muchas trabas que sufrió para crear las carmelitas descalzas.

[Teresa's character will be defined by two plots: the first, her encounters with Christ, periods of passion, sensuality that Loriga shoots with an almost dreamlike visual sense; and, on the other hand, Teresa's path/way of perfection until she convinces the ecclesiastical authorities that her mystical visions do not 
come from the devil but from God; the misunderstanding of his confessors and the many obstacles he suffered to found the Discalced Carmelites.]

(323-24)

Teresa's visions and her insistence on being able to communicate with Christ Himself are seen, in the historical context of the film, as highly suspicious by the Church hierarchy, starting with the Prioress of her first convent and especially by the Provincial of Ávila. Furthermore, the orthodoxy of her thinking and her plans to found a Carmelite convent will be probed on many occasions throughout the film. The climax of this resistance comes about halfway into the film in a trial-like scene (50:30) in which she faces a small all-male group of local government and Church officials that includes enemies, like the Provincial, as well as supporters. In the scene, Teresa fearlessly exposes the nature of her relationship with Christ. It is not a definitive victory for her but at least her unwavering determination is not stopped by this informal jury. In fact, Teresa will face many more battles along the way and when she finally manages to found her first convent as the film ends, the closing credits tell the viewer that "El pequeño convento de San José sobrevivió a un proceso judicial que duró más de dos años" [The small convent of San José survived a judicial process that lasted more than two years] (01:28:35). We are then left with the impression that what was shown in the film was just a prelude to her life-long struggles.

While in Teresa two threads crisscross throughout the film (her mystical experiences, which will be developed later on, and her never-ending entanglement with the Church), in Lope there is only one main thread, centered on the protagonist's life. The rationale for why the film is focusing on his life is evident in the following comment by Waddington: "Quizás porque... la mejor obra de la extensa producción de Lope fue su propia vida; tal vez porque su mejor espectáculo fue, precisamente, el que protagonizó él mismo" [Perhaps because... the best work of Lope's extensive output was his own life; 
perhaps because his best show was precisely the one he starred in himself] (Waddington). In sum, Lope is a tale of the playwright's life vicissitudes when he is still in the making. He first struggles to make ends meet when returning from war but upon finding his trade (writing), his poetic mastery will win hearts and open doors in the theater business, in which his innovative ideas will mark a before and an after. In Teresa, on the other hand, the filmmaker's approach to her life is less hagiographic. Although she does struggle throughout the film, we do not have a central climactic scene (at the end or at any other point in the film) where she comes out as an absolute "victor." In fact, the end of the film, when she finally manages to found her first convent, is fairly anticlimactic and the viewer is left with the taste of an incomplete Sisyphean battle rather than that of a hero who has vanquished and silenced her detractors.

\section{Literature: Authoresque Landscape (Part I) -The "Fêted Writing Scenes"}

Scenes of authors writing (and contemplating) and attention to writing spaces has become standard practice in recent literary biopics. ${ }^{14}$ This trope has served to reinforce the central role of the lives of the flesh and blood authors in the process of literary creativity. ${ }^{15}$ Indeed, by sprinkling the films with such scenes, the filmmakers remind the viewers of the strong link between life and literature, as it taps into our collective imagery of what is a literary genius. As Shachar has shown, this is one of the techniques employed by directors of recent literary biopics to create an authoresque landscape (Screening). Lope makes frequent use of this feature. In Teresa, however, these scenes are almost non-existent and only occur in the second half of the film. If we see Teresa writing, it is for a very brief moment and it is not the main focus of the scene.

Lope's first writing scene occurs, about 16 minutes into the film, ${ }^{16}$ after he witnesses a badly received play in a corral de comedias of a hospital, where the audience throws leeks and other vegetables at the actors to express their 
negative opinion. Lope starts writing a play at night and falls asleep at his desk. Two days later, we see him woken up by his sister, who was worried because he hadn't eaten anything during those two days. We are led to think that this scene constitutes the pivotal moment when he begins his journey as a playwright. It is a crucial scene in that it prepares the groundwork to establish Lope as the "renovator" of the Spanish stage, an important theme in the film. In Lope, the writing scenes have an additional function: to link sexual desire with creativity, which is another aspect of the contemporary literary biopic (Shachar, Screening 28). One example of this type of scenes is when Lope writes a poem to Filis (Elena Osorio) after their first sexual act (30:00-24).

In Teresa, the writing scenes have a different orientation. When we see her writing, she is presented more as a scholar than as a writer and these scenes tend to be very brief. Indeed, in the first one, which is preceded by a scene in which she illegally purchases a smuggled copy of a book by Erasmus, Teresa is merely taking notes (37:28-37). In the second and third writing scenes, the focus is not on the writing itself. On top of being extremely brief episodes of writing, they are quickly interrupted by somebody else: Doña Guiomar in the second (01:13:57-01:14:56) and the Prioress in the third (01:20:1901:23:37), in which we learn that the impetus for her writing comes merely at the request of the Bishop, to "poner todo por escrito" [put it all in writing] in case "pruebas de su buena fe" [proof of her good faith] are needed. The fourth-and last-writing scene is the very last shot of the film and includes a statement linking her writing to the literary sphere. If not for this message, the average viewer would have likely never guessed that the filmic biography watched was that of a writer, whose oeuvre, as the statement indicates, is considered "fundamental" to the Golden Age of Spanish literature. ${ }^{17}$ 


\section{Literature: Authoresque Landscape (Part II)-Blending Biography and Oeuvre}

In the contemporary literary biopic genre, as we mentioned before, another way to create an authoresque landscape is by weaving the authors' biography with their literary production. In Lope, Waddington saw more potential in the author's lyrical poetry, to intertwine life and literature, than in his dramatic output, so he attempted to integrate (albeit with a few licenses) the poems into the film's narrative. ${ }^{18}$ The borrowings from Lope's oeuvre include eight poems: 1) "Ojos de mayor gracia y hermosura"19 (19:03-46), which appears in the film when he is bringing his first play to Don Jerónimo Velázquez's house and meets for the first time his daughter (Elena Osorio); 2) "Contemplando estaba filis" (24:54-25:15), in which Lope expresses his love for Elena [it is an abridged and modified version which contains only a few stanzas]; 3) "Dulce filis, si me esperas" (30:00-24), after their first sexual relation (with Elena), to reminisce; 4) "Ya no quiero más bien que sólo amaros" (42:44-43:08), a poem that Lope sold to the Marqués de las Navas who, unbeknownst to Lope at first, would be used by Navas to court Isabel de Urbina [Only the last two stanzas are recited in the film]; 5) "Desde que viene la rosada aurora" (47:47-48:32), another poem sold by Lope to the Marqués that the latter will read at his party; 6) "Un soneto me manda hacer Violante" (49:18-50:09), a sonnet that is read by Lope at the party of the Marqués [only the first verse is modified to make it fit into the narrative of the film]; 7) "Una dama se vende a quien la quiera" (01:09:51-01:10:07), a poem that is recited at the end of the performance of his first play in front of the crowd [it is an abridged version which contains only five slightly modified verses] and constitutes an act of defiance against the reputation of Elena, her father, and his new "socio" [partner] Perrenot, resulting in a lawsuit for libel; and 8) "Desmayarse, atreverse, estar furioso" 
(01:34:06-01:35:07), the last poem, read in voice over in its entirety after the judge announces his verdict. The poems are for the most part well integrated into the storyline. "Contemplando estaba filis" and "Dulce filis, si me esperas" do provide the viewer with a deeper look into Lope's feelings toward Elena. The themes of "Ya no quiero más bien que sólo amaros" and "Desde que viene la rosada aurora" mesh fairly well with the storyline. However, they come across as "fillers" (maybe because they are read by the Marqués) and don't really advance the plot forward. Only "Un soneto me manda hacer Violante" (along with the acrostic poem about Perrenot) delivered at the party of the Marqués in front of all the guests, which establishes Lope's stature as a/the master of poets, and "Una dama se vende a quien la quiera" (the libel), which appears in a climactic scene toward the end of the film that serves to illustrate Lope's irreverent and insolent nature (and sets the stage for the subsequent trial scene), really bring something to the plot and film and are thus "crucial." A crucial poem means that if it were edited out, the film/plot would no longer make sense (like in the scene of the libel) or would be severely amputated (when "Un soneto me manda hacer Violante" is read). The other poems either merely echo what we see on screen (e.g., the two love poems written for Filis) or are mere embellishments (the first and last poems) or fillers (i.e., the two poems read by the Marqués).

In Teresa, the weaving of life and literature takes place on a different plane: by focusing on the cognitive-affective elements of her development (the mystical experiences that lead to her trajectory as writer and founder). Broadly speaking, rather than the life of Teresa de Ávila, what constitutes the central theme of Loriga's film is what is happening in her mind, her relationship with Christ. 
The film opens with an emotionally-charged introductory scene with brief night shots of people being tortured (hanging from the ceiling), an orgy, a procession, an auto-da-fé, bonfires along with a soundtrack composed of people screaming in the background of the voice over narration of the film's historical backdrop. These images and sounds create an atmosphere of fear and chaos, which will quickly contrast with the peaceful music and the overall tranquility of the cinematography when Teresa is first introduced to the viewers in the next scene. These two contrasting and emotionally-charged scenes (the one on the historical context and Teresa's first appearance on screen) are placed right before the opening credits of the film, thus establishing and determining the mood of the film. As Greg M. Smith showed in Film Structure and the Emotion System (2003), ${ }^{20}$ many filmic cues "can provide emotional information" and "play a part in creating a mood orientation or a stronger emotion." These include "facial expression, figure movement, dialogue, vocal expression and tone, costume, sound, music, lighting, mise-en-scène, set design, editing, camera (angle, distance, movement), depth of field, character qualities and histories, and narrative situation" (42). ${ }^{21}$ The filmic cues in Teresa's first screen appearance (see Figures 1a and 1b) are her slow motion walk through the doors, the chiaroscuro lighting (centering on her), the flying dove (symbol of love, peace, and the Holy spirit), the motif of the beam of light (symbol of the divine presence), in addition to the red color of her dress that will prime viewers' perception, since the color will subsequently be associated with Christ's blood (see for instance the image of the bloody hand of Christ on the cross, part of the second tableau in Figure $8 \mathrm{~b}) .{ }^{22}$ 


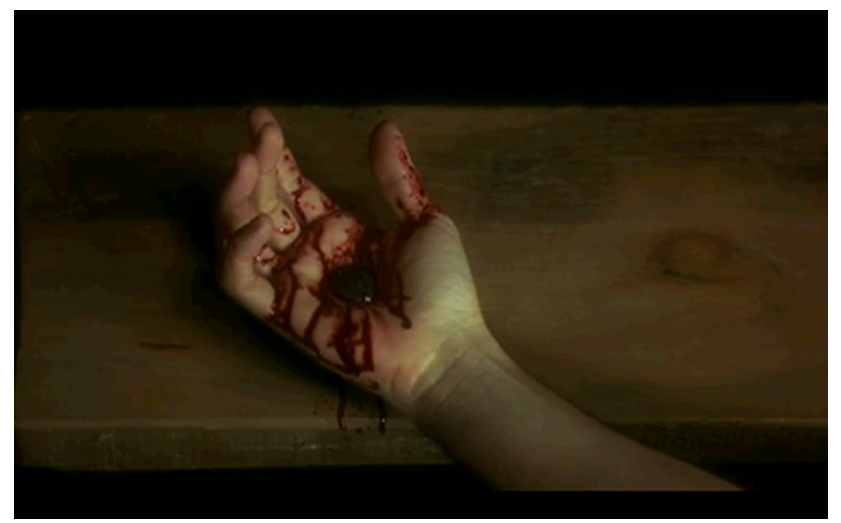

Figure $8 \mathrm{~b}-$ Tableau 2: The bloody hand of Christ on the cross (41:03)

Overall this scene predisposes viewers toward the seclusion from the harsh realities of the outside world and it guides them toward the introspective side of Teresa's philosophy and writings. ${ }^{23}$ Indeed, the doors that she is walking through (see Figure 1a) are those of the moradas [Mansions] that lead to Christ, a metaphor that forms the basis of her work, El castillo interior (The Interior Castle) or Las moradas (The Mansions 1577/1588).

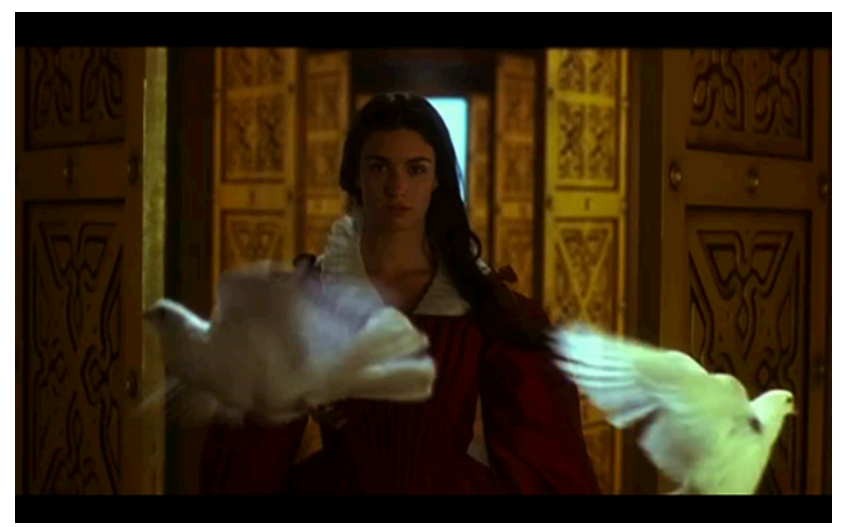

Figure 1a-Morada scene 1: Teresa walks through the doors of the moradas (03:03) 


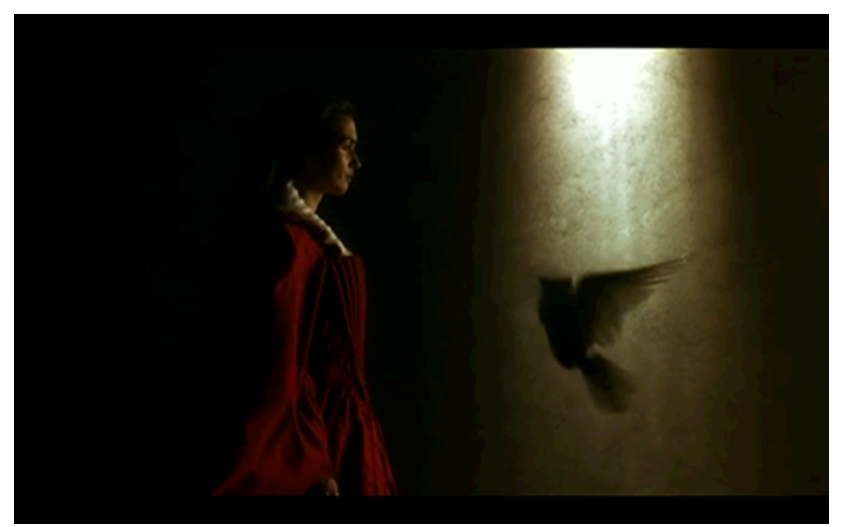

Figure 1b-Morada scene 1: Teresa with flying dove and beam of light (03:15)

While in Lope, poems are for the most part used to show the poet's prowess, in Teresa they reveal the protagonist's state of mind. The first poem, "Vuestra soy, para Vos nací," which is read by the actress Paz Vega (Teresa) in voice over (in the scene described above) as she walks through the various doors, is a good illustration of Loriga's different approach:

\footnotetext{
Vuestra soy, pues me criasteis, vuestra, pues me redimisteis, vuestra, pues que me sufristeis, vuestra pues que me llamasteis, vuestra porque me esperasteis, vuestra, pues no me perdí:

¿qué mandáis hacer de mí? (02:20-03:06) ${ }^{24}$
}

The anaphora ("vuestra" [Yours/Thine]) emphasizes the closeness of the relationship between Christ and Teresa, a crucial motif in the film ${ }^{25}$ that will be reinforced throughout the story, along with the idea of Christ as Teresa's husband. ${ }^{26}$ As Loriga attempts to portray Teresa's mystical love, the "romantic" relationship between Christ and Teresa and its influence in Teresa's literary 
production is a complete reversal of the rom-com-ish approach of the recent literary biopics, where creativity is fueled by love interest (see Shachar, Screening). The blurring of sensual and spiritual love, a theme often discussed in connection to Teresa's writings and to other mystics of the epoch, is verbally introduced when she confesses to Gaspar Daza, "el amor que me perdió y acabó por salvarme" [the love that led me astray and ended up saving me] (07:25). In the following flashback scene, she explains that the "love that led her astray" was her first romantic encounter, which we assume was consummated in light of the subsequent conversation with her father as well as the image of the thorn rose pressing into her skin and letting a few droplets of blood roll down her body as she is embraced by her lover (08:00). When her father tells her that "No hay hombre que pueda ya quererte" [No man can love you now] (08:35), she responds that "Yo sé de uno" [I know of one].

The sensuality of Teresa's relationship with Christ reaches its apex soon after in a continuation of the moradas scene 1, as Teresa now reaches the last morada, which in El castillo interior is where Christ can be found. We see her walking through the doors of several moradas again and eventually after the last door, Christ appears (see Figure 2a). The soothing musical theme is similar to the first morada scene and once more Teresa is reading in voice over a poem, "Si el amor que me tenéis." ${ }^{27}$ As the second stanza starts ("Alma, ¿qué quieres de mí?" [Soul, what do you want of me?], Teresa enters the last morada. Her wish ("no más que verte" [only to see You]) is granted and she now stands before Christ (see Figure 2a). As the third stanza begins ("Un alma en Dios escondida / ¿qué tiene que desear" [A soul hidden in God / what can 
it wish for?], Christ is standing behind her and He starts caressing her bare arm (see Figure $2 \mathrm{~b}$ ). The wound in the middle of His hand unequivocally lets the viewers know that we are in the presence of Christ Himself.

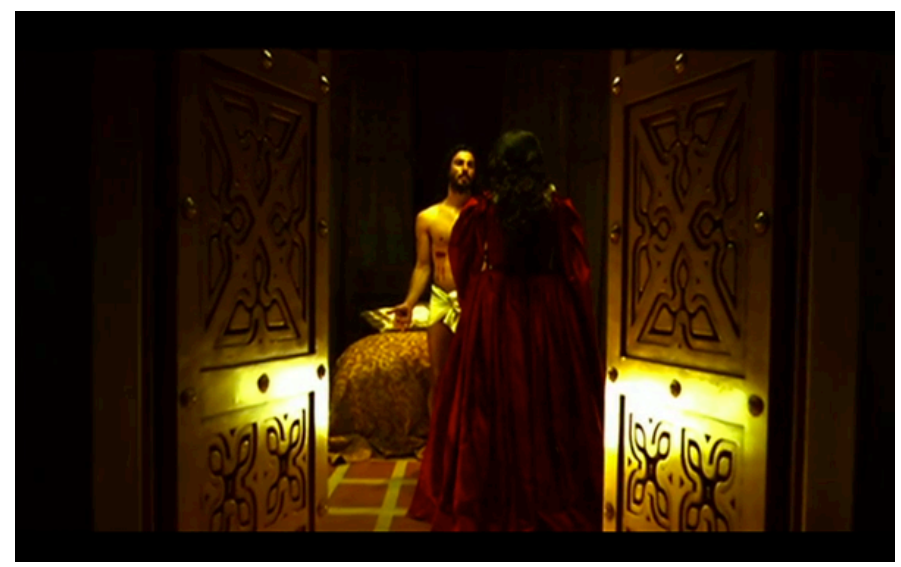

Figure 2a-Morada scene 2: Teresa standing before Christ in the last morada (18:29)

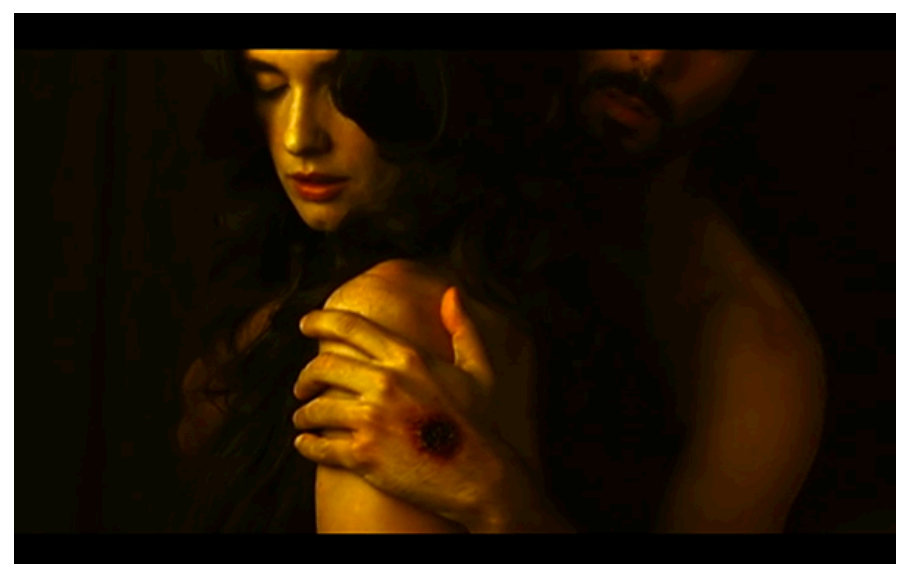

Figure 2b-Morada scene 2: Christ caressing Teresa's bare arm (18:39) 
The pinnacle of the sexualization/sensualization of her relationship with Christ occurs when His hand reaches hers and her bare left buttock is revealed (see Figure 2c), just as we hear the penultimate verse " $y$ en amor toda encendida" [and, burning in that love].

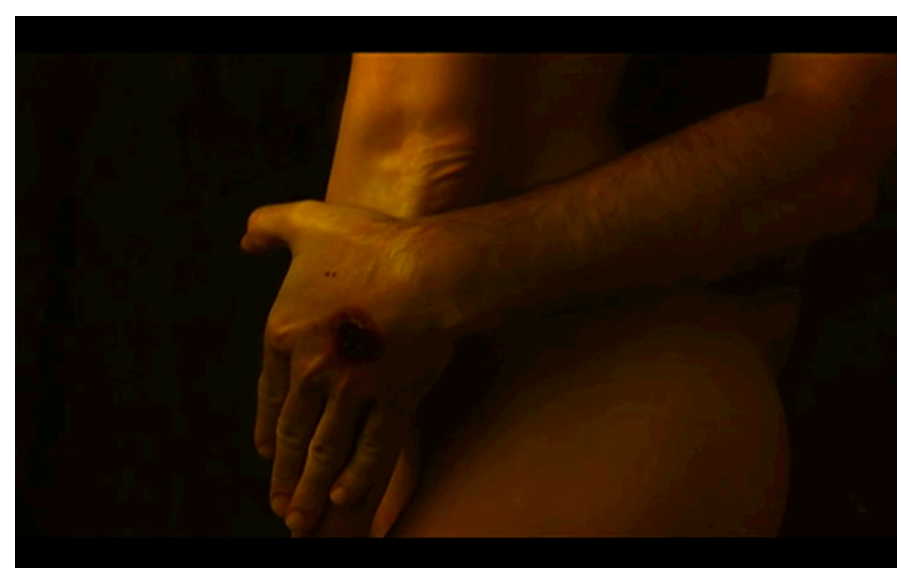

Figure 2c-Morada scene 2: Christ's hand reaches Teresa's (18:45)

This scene is also another illustration of how poems are used to represent what is happening in Teresa's mind. And in this case, the poem is symbiotically echoing what is visually taking place on screen.

The encounter with Christ, in this second morada scene, not only constitutes the apex of the muddling of Teresa's carnal and spiritual love, it is also a pivotal scene in that from now on her desire to reach Him will also anguish her, as she tries to transcend her carnal love. This psychological transformation will be visually conveyed throughout the rest of the film (as we will see below) and the end of her quest toward a purely spiritual love for Christ will, visually speaking, occur toward the end, when we last see her bare (and flagellated) 
body as she substitutes her old habit of the Convent of La Encarnación to wear the modest habit-following the precepts of the "vieja regla" [old rule]—of her new Convent of the Discalced Carmelites (see Figure 11).

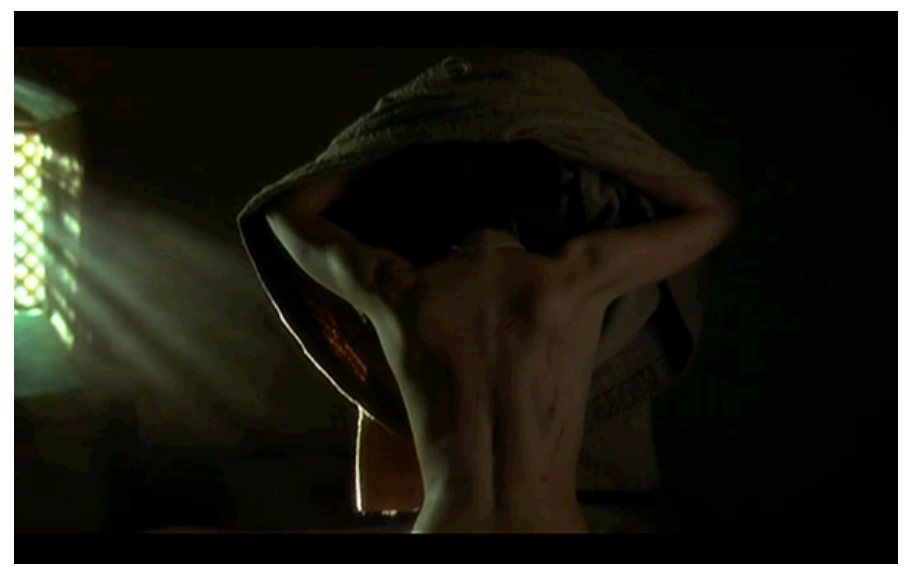

Figure 11-Last shot of Teresa's body: Donning the modest habit of her newly formed Convent of the Discalced Carmelites (01:24:56)

In the creation of a "Teresianesque landscape," another scene also stands out. It is the flip side of the more sensual attempt to reach Christ that is just described above. Instead of being united in "love," Teresa desires to be united in "death." The anguish provoked by her encounter with Christ in the second morada scene will drive her to right away flagellate herself and later on to wear a cilicio [cilice] around her waist to do penance and expiate her sins (see Figure 3). 


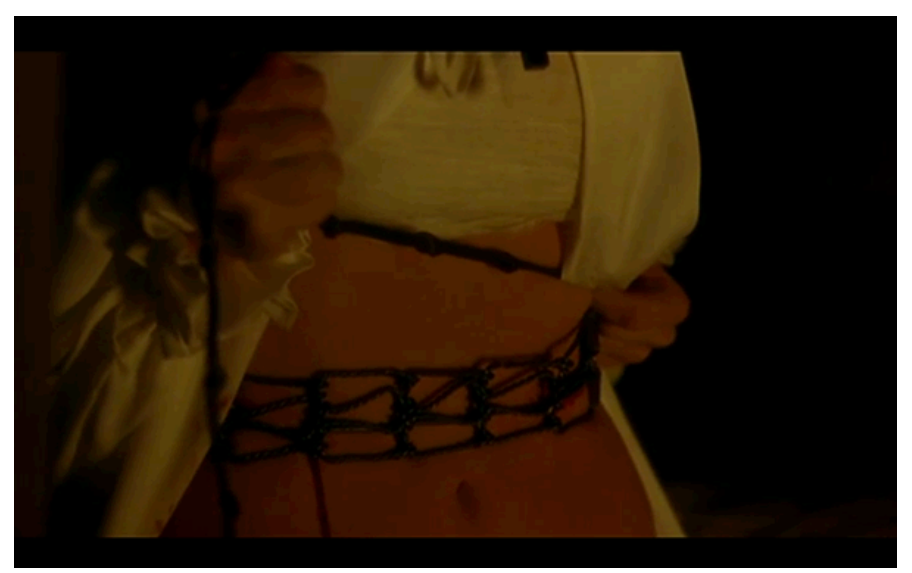

Figure 3-Teresa's mortification with a cilicio (22:10)

The mortification of her body will eventually debilitate her to the point of needing medical attention. Nearing death, Teresa is carried away by nuns wearing black through a chapel turned slaughterhouse with pieces of meat hanging (see Figure 5), as the eighth stanza of her poem "Ayes del destierro" (or “¡Cuán triste es, Dios mío...!”) is read in voice over: “Mi alma afligida / Gime y desfallece / ¡Ay! ¿Quien de su amado / Puede estar ausente? / Acabe ya, acabe / Aqueste sufrir. / Ansiosa de verte / Deseo morir" ["My afflicted spirit / Sighs and faints away. / Who from his Beloved / Absent long can stay? / Let my bitter suffering / Vanish speedily, / Since my yearning for Thee / Makes me long to die." (Vol. 3 of Complete Works 286)] (26:58-27:15; emphasis added). This stanza echoes the plotline, as it symbolizes her impatience and desire to die so she can be united with Christ in Heaven. 


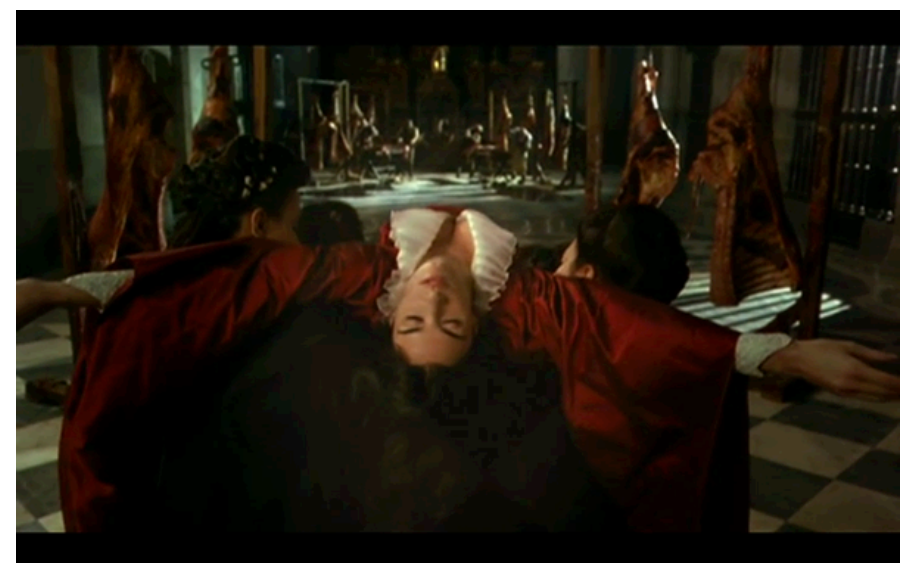

Figure 5-Teresa carried away cross-like through pieces of meat (26:52)

In this scene, the image of the slaughterhouse can be understood as a metaphor of death and the bloodiness associated with it can be seen as a mood cue of the Blood of Christ (see also Figures 2a, 2b, 2c, 3, 6, 8a, 8b, 9, 10a, 10b, 10c). Her cross-like body position (see Figure 5) also signals that she is anxious to be reunited with Christ on the cross. The entire scene could also be interpreted as a "pre-funeral" for Teresa, whom we see in the next scene lying dead and being mourned in a room of the convent, a grave open on the floor to receive her. ${ }^{28}$

\section{Visual Representations of Teresa's Mind/Interiority}

In Teresa, Loriga not only blends life and literature to create an authoresque landscape by visually representing themes and motifs of her writings, he also forays into her interiority by cinematographically transposing her inner mystical experiences: her transverberation (or religious ecstasy) (Figures 4, 7a and 7b) and her mystical visions, represented in the film as tableaux (Figures $6,8 \mathrm{a}, 9$ and 10a). 
In chapter 29 of her autobiography (titled Vida de Santa Teresa de Jesús [The Life of the Holy Mother Teresa of Jesus]), Teresa describes her transverberation as follows:

It pleased the Lord that I should sometimes see the following vision. I would see beside me, on my left hand, an angel in bodily form... He was not tall, but short, and very beautiful, his face so aflame that he appeared to be one of the highest types of angel who seem to be all afire. They must be those who are called cherubim... In his hands I saw a long golden spear and at the end of the iron tip I seemed to see a point of fire. With this he seemed to pierce my heart several times so that it penetrated to my entrails. When he drew it out, I thought he was drawing them out with it and he left me completely afire with a great love for God. The pain was so sharp that it made me utter several moans; and so excessive was the sweetness caused me by this intense pain that one can never wish to lose it, nor will one's soul be content with anything less than God. (Vol. 1 of Complete Works 192-93) ${ }^{29}$

In Loriga's representation of the transverberation, the cherub of small stature is replaced by an adult size angel (see Figure $7 \mathrm{~b}$ ). The representation of the “long spear of gold" appears in the second transverberation scene (see Figure $7 a$ ), while in the first one several of these spears pierce through her body (see Figure 4). 


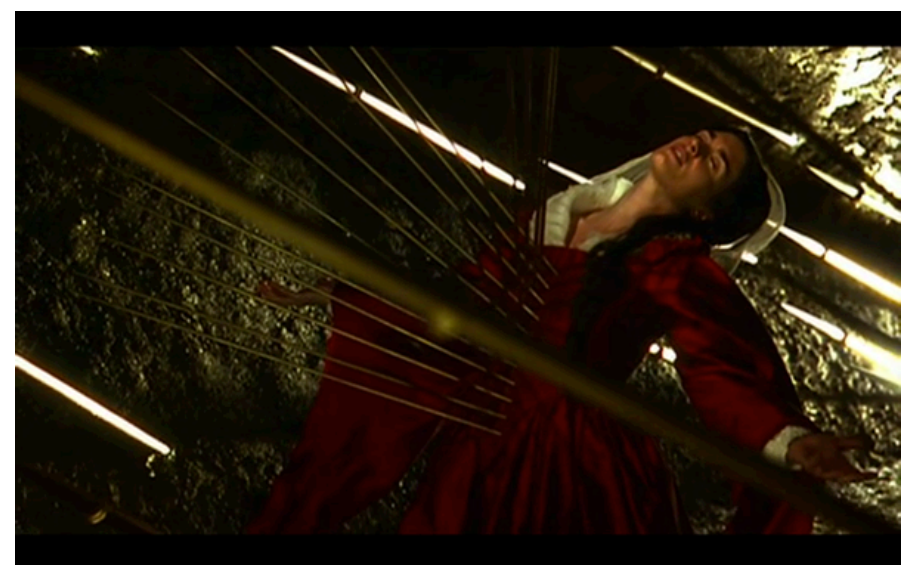

Figure 4-Transverberation scene 1 (22:54)

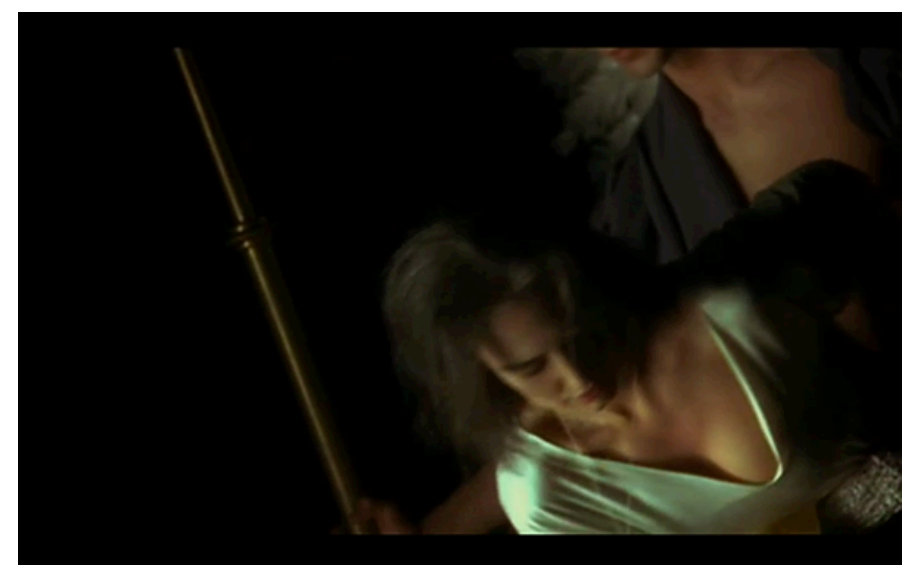

Figure 7a-Transverberation scene 2: With "long spear of gold" (38:11) 


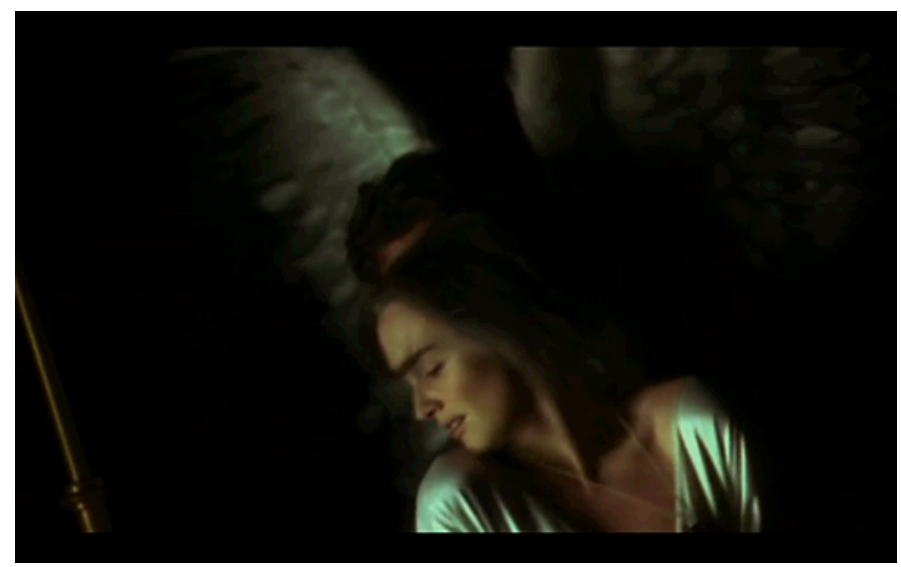

Figure 7b-Transverberation scene 2: With angel (38:10)

As mentioned above, in Loriga's film Teresa's visions take the form of tableaux, featuring flesh and blood actors (albeit immobile). The presence of real actors in the tableaux emphasizes once more the carnality of Teresa's writings and her relationship with Christ. Indeed, the presence of Christ in her visions is not abstract but real and embodied. For instance, in chapter 37 of her autobiography, she states that:

Once I had seen this Lord, I was so continually in converse with Him that my love for Him and trust in Him began to increase greatly. I saw that, although God, He was also Man... Although He is my Lord, I can talk to Him as to a friend, because He is not, I believe, like those whom we call lords on earth, all of whose power rests upon an authority conferred on them by others. Such lords have fixed hours for audiences and persons whom they appoint for the purpose of speaking with them. (Vol. 1 of Complete Works 263) $)^{30}$

The "Christ is a man too" theme forces Loriga to take Him down His pedestal and to humanize Him. Translating this goal into the language of cinematography, 
Loriga eliminates the distancing devices (such as tracking shot, dissolve, etc. or any of the devices often employed by filmmakers to signal to the viewer a shift to a dream sequence, a thought, an anticipation of future events, etc.). The transitions between these visions and the plotline occur seamlessly. Loriga employs what we could call a "cinematic free indirect discourse" whereby the transition from the film narrative to the mind of the protagonist (in this case Teresa's visions as represented by the pictorial tableaux) is continuous, uninterrupted by cinematic devices.

These tableaux, in addition to the two transverberation scenes, form a visual narrative of Teresa's state of mind: cognitive and affective, as well as her developmental process.

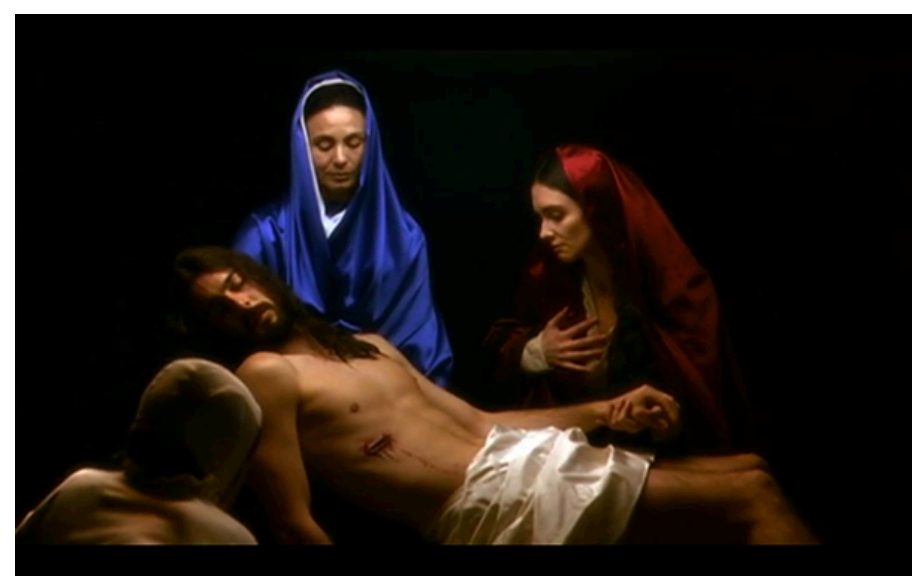

Figure 6-Tableau 1: The Pietà with Teresa as Mary Magdalene (32:09) 


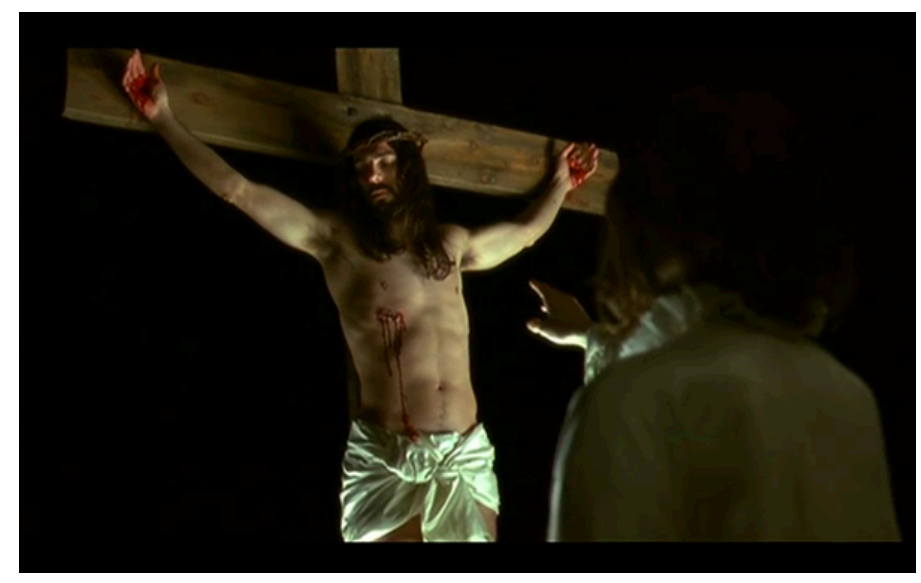

Figure 8a-Tableau 2: Christ on the cross (40:47)

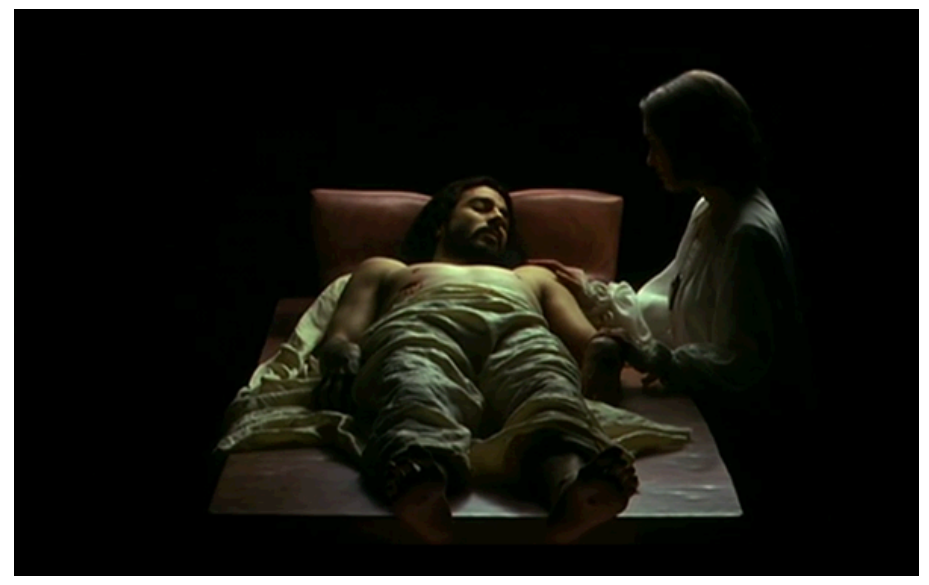

Figure 9-Tableau 3: The Lamentation of Christ (44:27) 


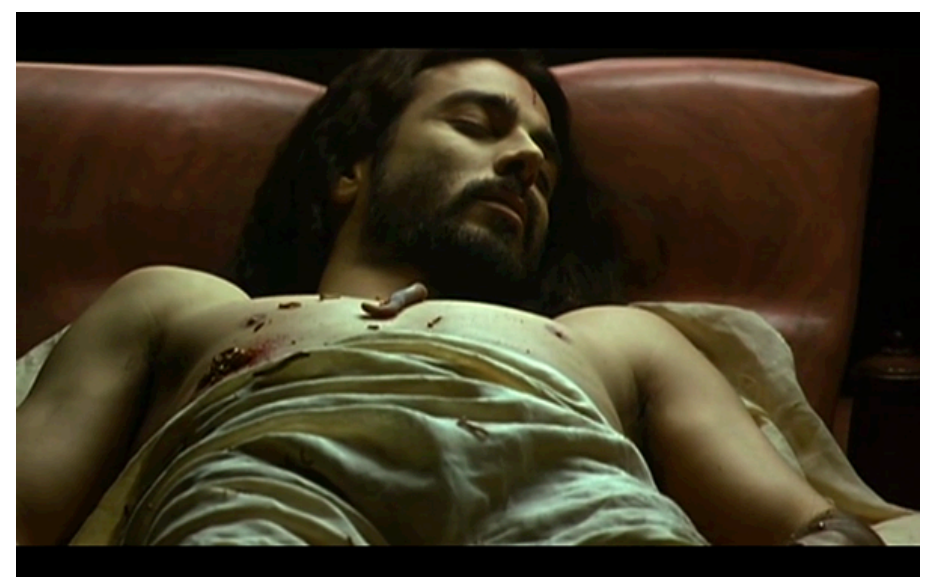

Figure 10a-Tableau 4: The Lamentation of Christ with crawling worms (57:00)

As we saw, at various points in the film Teresa is experiencing doubts about her visions. She is unsure of whether they will take her on the right path or if they are acts of the Devil. These doubts are instilled with vigor in Teresa's psyche during the trial-like scene. The result of these efforts on the part of her detractors (and supporters too) thus lead her to confront the Devil. In the following scene, we see Teresa walking around her cell, in the middle of the night, defiantly holding up a crucifix to face Him. This scene then segues into a variant of Tableau 3's Lamentation of Christ (see Figure 9), which reflects her state of mind. 


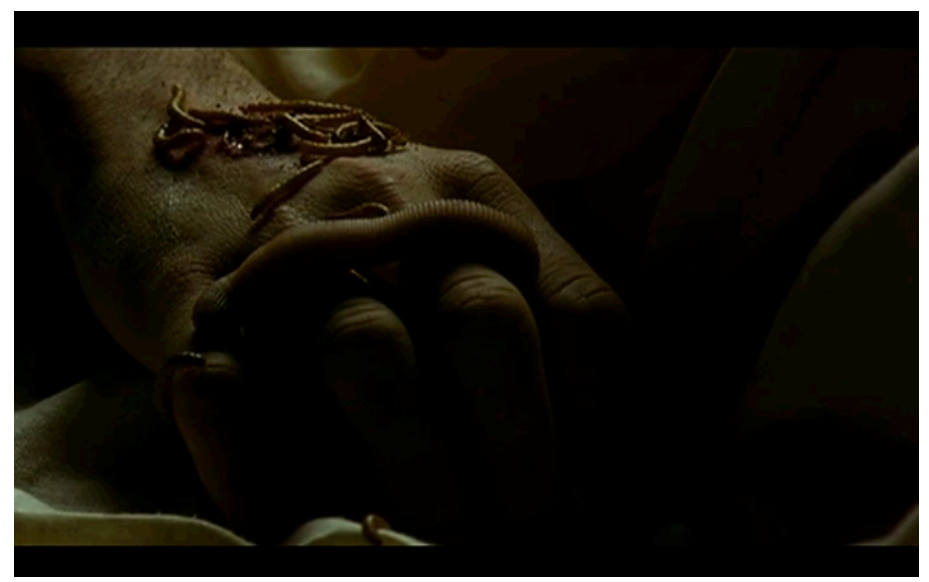

Figure 10b-Tableau 4: Worms entering Christ's wound in His hand (56:43)

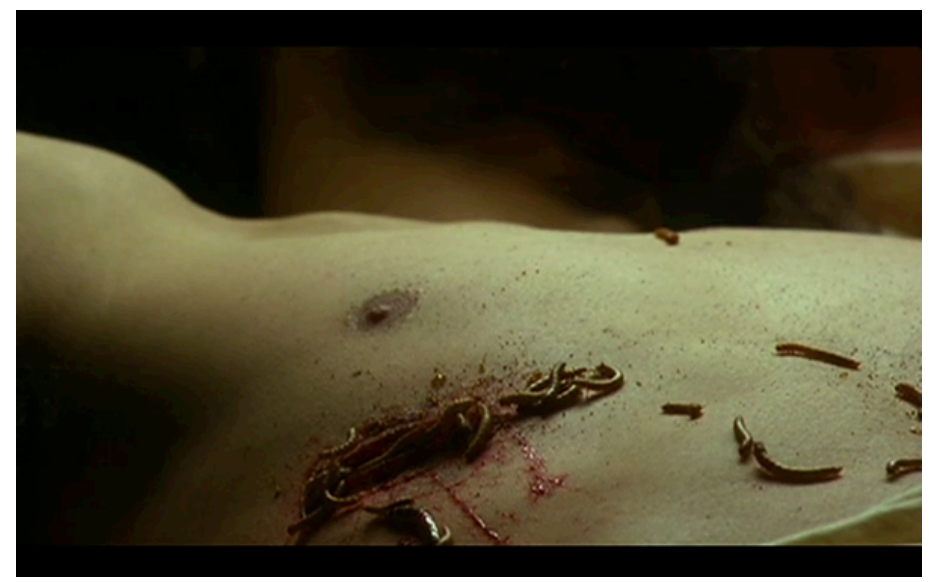

Figure 10c-Tableau 4: Worms entering Christ's wound in His waist (56:45) 
Indeed, Tableau 4 (see Figure 10a) no longer exhibits the tranquility of mind and plenitude of Tableau 3. It has been corrupted, eaten up as she was by doubt and fear. The visual transcription of her psychological torment is illustrated by the crawling worms that enter Christ's body via the wounds in His hand (see Figure 10b) and waist (see Figure 10c). The worms are for Loriga what the sabandijas of El castillo interior were for Teresa: that is, devilish reptiles whose scheme, symbolically speaking, is "para que las almas no se conozcan ni entiendan sus caminos" [so that souls do not know themselves or understand their ways].

Tableau 4 is the last vision of Teresa in the film and from this point forward the visuality of the film will gradually diminish. There will be no more moodcueing shots or visual representations of Teresa's mind or of the historical context. That is also when writing scenes-though not given as much weight and emphasis as in Lope or other standard literary biopics-will become more frequent.

\section{Conclusion}

Lope and Teresa are in many respects similar endeavors. They bring to the silver screen the life of two revered literary figures of the Spanish Golden Age. Nevertheless, Lope mostly follows the formula of many contemporary literary biopics (mainly Anglo-Saxon ${ }^{31}$ ), which aims at establishing an authoresque landscape including writing scenes and weaving the life with the work of the writer to compose the storyline. Teresa, on the other hand, deviates from this formula. Not only are writing scenes virtually absent but, more importantly, what is mainly transposed onto the screen are not the plot-driven narrative aspects (i.e., life events in connection to Teresa's work), but the cognitive-affective ones (i.e., her state of mind, emotions, and psychological development). Through image and mood as the central cinematographic elements, Loriga creates a biopic where the interiority of the writer is at the 
core. Herein lies the innovation of Loriga's approach vis-à-vis the "formula." ${ }^{32}$ Centering on the author's mind can be a new path for filmmakers to innovate and move away from more familiar formulae of the biopic, to tweak its conventions, particularly in its literary strand. While other film scholars have pointed at how the use of irony (Lupo and Anderson) and parody and selfreflexivity (Bingham 19) constitute ways to deviate from the standard biopic, in the sub-genre of the literary biopic, the shift from the life to the mind of the writer can also be a way to renovate and keep breathing new life into the genre. Finally, it is important to point out that the scholarly conversation about the contemporary literary biopic genre should expand beyond the confines of the English-speaking world. The two biopics discussed here make this need patent, as they both engage with and deviate from the formula established by Anglo-Saxon biopics.

\section{Notes}

Unless otherwise noted, all translations are mine.

1 The "becoming" trope appears in many of the biopics that came out before or around the same time as Lope and Teresa-examples are Shakespeare in Love, Becoming Jane or Young Goethe in Love. For more details on this feature of the contemporary literary biopic, see among others Shachar, Screening.

2 Here, I am slightly transforming Hila Shachar's concept of "Austenesque landscape" from her recent book, Screening the Author: The Literary Biopic (2019).

3 See especially chapter 2 of her book, Screening the Author (2019).

4 For a study on the connection between the literary adaptations and literary biopics genre, see Indrusiak and Ramgrab.

5 For an in-depth discussion of the ideological aspects of contemporary literary biopics, see Shachar, Screening.

6 For an industry-related historical analysis of Spanish cinema, see among others Duncan Wheeler's 2014 essay "Back to the Future: Repackaging Spain's Troublesome Past for Local and Global Audiences."

7 Lope's budget was about $€ 13$ million [ $\sim 18$ million] (“Leonor") but, according to Box Office Mojo, only grossed worldwide $\$ 5,207,679$ and was released in theaters 
only in Spain, Brazil and Lithuania ("The Outlaw"). Teresa's estimated budget was $\$ 10$ million ("Theresa" in IMDb) but, according to Box Office Mojo, grossed worldwide a mere $\$ 898,401$ and was released in theaters in two countries only: Spain and Portugal ("Theresa” in Box Office Mojo).

8 For a more general discussion about this topic, see Rosenstone. For a more detailed analysis of the level of "historical truth" in Lope, see Carmona, "Lope"; Carmona, Las reescrituras. And for Teresa, see García-Sánchez.

9 They were contemporaries. Cervantes was born in 1547 and Lope fifteen years later in 1562.

10 See for example the ARTELOPE database.

11 Custen defined it as “the hero's antagonistic relations with the members of a given community" (72).

12 The "¿Qué dirán?" often evidences the persistence in Spanish society to live above one's means and preserve the image of an opulent and grandiose past at a time of decay when the Spanish Crown can no longer protect and financially support its empire.

13 This emphasis on the socio-cultural context led Sally Faulkner in A History of Spanish Film (2013) to argue for the importance of pedagogy in the film (see pp. 272-78).

14 Judith Buchanan, for instance, explains that: "Literary biopics make a feature of shots that lovingly fête the writing process. We are familiar with aestheticized views of desk, quill, parchment, inkpot, typewriter, the writer in a moment of meditative pause, the evocatively personal oddities that adorn the space of writing, the view from the window as a reflective space that feeds the imaginative process... It is, typically, the cumulative effect of these recurring shots rather than the particular character of any one that seasons the film. And, by extension, it is the cumulative effect of these recurring shots across films that generates a sense of consoling familiarity and of a visual terrain reassuringly easy to navigate for the generically attuned spectator" ("Introduction" 5-6). See also Shachar, Screening; especially pp. 24-28.

15 In doing so, it questions the current literary scholars' theories of authorship of Barthes and Foucault. For more details on these analyses, see for instance Elliott; Shachar, Screening.

16 Contrary to what happens in Becoming Jane for example, the first writing scene occurs fairly late in the film. Within the narrative logic of the film however, it 
makes sense as Lope was not actually "born" with a passion for letters. It is "by chance" that he discovers the joys of writing verses and plays. In the film, the impetus for writing comes from a desire to socially ascend. That's why the first writing scenes does not occur early on, like in most recent literary biopics.

17 The full statement says: "Sus escritos son considerados parte fundamental del Siglo de Oro de la literatura Española” [Her writings are considered fundamental to the Golden Age of Spanish literature] (01:29:09).

18 For more details on the poetic licenses in Lope, see Carmona, "Lope"; López López.

19 All the poems by Lope are identified by their first verse.

20 See especially chapter 3, “The Mood-Cue Approach to Filmic Emotion," pp. 41-64.

21 To this list of cues, Isabel Jaén Portillo has suggested the addition of the "empathic energy generated by the transmission of affect among bodies" (par. 17).

22 In this essay, figures are numbered in the order of appearance in the film so that the reader can appreciate how its visual narrative evolves. If several screenshots are taken from the same scene, a letter is added. Thus, Figure 8b corresponds to the second screenshot of the eighth scene analyzed.

23 Direct reference to her concept of a castillo interior occurs twice in the film: when speaking with her main confessor Gaspar Daza (07:00) and with "el hombre Santo" [the Holy man], Fray Pedro de Alcántara (01:01:31).

24 "Thine I am, for Thou didst make me; / Thine, for Thou alone didst save me; / Thine-Thou couldst endure to have me; / For Thine own didst deign to take me. / Thine I am: Thou didst await me / Ruined were I but for Thee: / What wilt Thou have done with me?" (Vol. 3 of Complete Works 279).

25 For instance, in a confession early on in the film she reveals that she wants to see His face "tan cerca de la [suya] que ya nada nunca [los] separe" [so close to hers that nothing can separate them] (00:11:35).

26 The visual transposition of this theme will be discussed later on. In the dialogues, it is directly referenced twice: when speaking to her main confessor Gaspar Daza for the first time (00:06:16) and another dialogue with him responding to his question: “¿Quién se cree que es?” [Who do you think you are?], she says “¿Quién soy? ...su esposa" [Who am I? ...his wife] (44:14-28). 
27 "Si el amor que me tenéis, / Dios mío, es como el que os tengo; / Decidme ¿en qué me detengo? / O Vos, ¿en qué os detenéis? // -Alma, ¿qué quieres de mí? | -Dios mío, no más que verte. -Y ¿qué temes más de ti? | -Lo que más temo es perderte. // Un alma en Dios escondida / ¿qué tiene que desear, / sino amar y más amar, / y en amor toda encendida / tornarte de nuevo a amar?" ["God, if Thy love so great and high / Is like the love I have for Thee, / Why do I wait so doubtfully? / Why dost Thou wait to let me die? // 'Soul, what is this thou dost desire?' / 'Only, my God, to see Thy face.' / 'What dost thou fear so dread and dire?' / 'That I may haply lose Thy grace.' // Oh, when a soul is hid in Thee, / For what adventure can it yearn / Save love and still more love to learn, / And thus to love increasingly, / So deep does love within it burn?" (Vol. 3 of Complete Works 282-283)] (18:01-50).

28 Teresa suffered a near-death experience, which she relates in chapter 5 of her autobiography as follows: "Dióme aquella noche un parajismo, que me duró estar sin ningun sentido cuatro dias, poco menos: en esto me dieron el sacramento de la Uncion, y cada hora y memento pensaban espiraba, y no hacian sino decirme el credo, como si alguna cosa entendiera. Teníanme á veces por tan muerta, que hasta la cera me hallé despues en los ojos... [T]íniendo dia y medio abierta la sepoltura en mi monesterio, esperando el cuerpo allá, y hechas las honras en uno de nuestros frailes, fuera de aquí, quiso el Señor tornase en mí" ["That night I had a fit, which left me unconscious for nearly four days. During that time they gave me the Sacrament of Unction, and from hour to hour, from moment to moment, thought I was dying; they did nothing but repeat the Creed to me, as though I could have understood any of it. There must have been times when they were sure I was dead, for afterwards I actually found some wax on my eyelids... For a day and a half there was an open grave in my convent, where they were awaiting my body, and in one of the monasteries of our Order, some way from here, they had performed the rites for the dead. But it pleased the Lord that I should return to consciousness." (Vol. 1 of Complete Works 30-31)] (Escritos 31).

29 The original text in Spanish was: “Quiso el Señor, que viese aquí algunas veces esta vision: via un ángel cabe mí hácia el lado izquierdo en forma corporal... [N]o era grande, sino pequeño, hermoso mucho, el rostro tan encendido, que parecia de los ángeles muy subidos, que parece todos se abrasan. Deben ser los que Ilaman cherubines... Veíale en las manos un dardo de oro largo, y al fin del hierro me parecía tener un poco de fuego. Este me parecia meter por el corazon algunas veces, y que me llegaba á las entrañas: al sacarle me parecia las llevaba consigo, y me dejaba toda abrasada en amor grande de Dios. Era tan grande el 
dolor, que me hacia dar aquellos quejidos, y tan ecesiva la suavidad que me pone este grandísimo dolor, que no hay desear que se quite, ni se contenta el alma con menos que Dios." (Escritos 89-90)

30 The original text in Spanish was: "Comenzóme mucho mayor amor, y confianza de este Señor en viéndole, como con quien tenia conversacion tan contina. Via que aunque era Dios, que era hombre... Puedo tratar como con amigo, aunque es Señor, porque entiendo no es como los que acá tenemos por señores, que todo el señorío ponen en autoridades postizas. Ha de haber hora de hablar, y señaladas personas que les hablen." (Escritos 114)

31 Some of the relevant studies on the literary biopic that have sought to survey the genre and analyze its evolution and/or characteristics include: Buchanan, The Writer; Elliott; Higson; Shachar, "Authorial”; Shachar, Screening. They almost exclusively deal with British biopics. The notable exception is Crespo Steinke, which compares the following British, French and German biopics: Shakespeare in Love, Molière and Young Goethe in Love, respectively.

32 We must point out that a few other films that came out in the 2000s attempted to also deviate from the formula, using a variety of approaches via visual images, dreams, sounds, etc. These include Finding Neverland (Marc Forster 2004) on Scottish dramatist J. M. Barrie, Miss Potter (Chris Noonan 2006) on English illustrator and children's book author Beatrix Potter, Pandaemonium (Julien Temple 2000) on English poets Samuel Taylor Coleridge and William Wordsworth, and Time Regained (Raoul Ruiz 1999) on French novelist Marcel Proust.

\section{Works Cited}

ARTELOPE: Base de datos y argumentos del teatro de Lope de Vega. http://artelope.uv.es/ basededatos/Accessed 3 Aug. 2020.

Bingham, Dennis. Whose Lives Are They Anyway? The Biopic As Contemporary Film Genre. Rutgers UP, 2010.

Buchanan, Judith. "Introduction: Image, Story, Desire: The Writer on Film." The Writer on Film: Screening Literary Authorship, edited by Judith Buchanan, Palgrave, 2013, pp. 3-32.

Buchanan, Judith, editor. The Writer on Film: Screening the Literary Authorship. Palgrave, 2013. 
Carmona, Alba. “Lope de Andrucha Waddington: Una biografía del Fénix para el lienzo de plata." Hipogrifo: Revista de Literatura y Cultura del Siglo de Oro, vol. 4, no. 2 , 2016, pp. 123-134.

Carmona, Alba. Las reescrituras filmicas de la comedia nueva: Un siglo en la gran pantalla. Peter Lang, 2019.

Crespo Steinke, Carolin. "Travelling through the Centuries: The Intertextual Relationship between Shakespeare in Love, Molière and Young Goethe in Love." English Text Construction, vol. 10, no. 1, 2017, pp. 59-77.

Custen, George Frederick. Bio/pics: How Hollywood Constructed Public History. Rutgers UP, 1992.

Elliott, Kamilla. "Screened Writers." A Companion to Literature, Film, and Adaptation, edited by Deborah Cartmell, Wiley-Blackwell, 2012, pp. 179-197.

Faulkner, Sally. A History of Spanish Film: Cinema and Society, 1910-2010. Bloomsbury, 2013.

García-Sánchez, M. Soraya. "Teresa, the Erotic Saint? A Journey to Paz Vega's Acting in Theresa: The Body of Christ." The Erotic in Context, edited by M. Soraya GarcíaSánchez, Cara Judea Alhadeff and Joel Kuennen, Inter-Disciplinary P, 2011, pp. 109-116.

Higson, Andrew. "Brit-lit Biopics, 1990-2010." The Writer on Film: Screening the Literary Authorship, edited by Judith Buchanan, Palgrave, 2013, pp. 106-120.

Indrusiak, Elaine, and Ana Iris Ramgrab. "Literary Biopics: Adaptation as Historiographic Metafiction." The Routledge Companion to Adaptation, edited by Dennis Cutchins, Eckart Voigts and Katja Krebs, Routledge, 2018, pp. 97-105.

Jaén Portillo, Isabel. “Body, Interiority and Affect in Memoria Histórica Cinema: Can Cinema of Empathy Advance the Cause of the Victims of Fascism? Langage intérieur - Espaces intérieurs / Inner Speech - Inner Space, edited by Stéphanie Smadja and Pierre-Louis Patoine, special issue of Épistemocritique, vol. 18, 10 Dec. 2018, http://epistemocritique.org/body-interiority-and-affect-in-memoria-historicacinema-can-cinema-of-empathy-advance-the-cause-of-the-victims-of-fascism/ Accessed 3 Aug. 2020.

“Leonor Watling y Pilar López de Ayala, las amantes de 'Lope." Fotogramas, 21 Apr. 2009, http://www.fotogramas.es/noticias-cine/a318730/leonor-watling-y-pilar-lopezde-ayala-las-amantes-de-lope/\# Accessed 1 Aug. 2020. 
Lope. Directed by Andrucha Waddington, performances by Alberto Ammann, Leonor Watling and Pilar López de Ayala, Twentieth Century Fox Home, 2010.

López López, Yolanda. El Siglo de Oro en el cine y la ficción televisiva: Dirección artística, referentes culturales y reconstrucción histórica, Madrid, Asociación Cultural y Científica Iberoamericana, 2017.

Lupo, Jonathan, and Carolyn Anderson. "Off-Hollywood Lives: Irony and Its Discontents in the Contemporary Biopic." Journal of Popular Film and Television, vol. 36, no. 2, 2008, pp. 102-112.

Martín-Pérez, Celia. "A Woman for All Seasons: Teresa of Ávila on Spanish Screens." Seeing in Spanish: From Don Quixote to Daddy Yankee - 22 Essays on Hispanic Visual Cultures, edited by Ryan Prout and Tilmann Altenberg, Cambridge Scholars, 2011, pp. 18-31.

Morley, S. Griswold, and Courtney Bruerton. "How Many Comedias Did Lope de Vega Write?” Hispania, vol. 19, no. 2, 1936, pp. 217-234. JSTOR, http://doi. org/10.2307/332239 Accessed 3 Aug. 2020.

“The Outlaw (2010)." Box Office Mojo, http://www.boxofficemojo.com/title/ $\underline{t t 1186357 / \text { ?ref }=\text { bo } t t ~ t i}$ Accessed 1 Aug. 2020.

Rosenstone, Robert A. History on Film/Film on History. Pearson, 2012.

Saint Teresa of Avila. The Complete Works of St. Teresa of Avila: Vol. 1. Translated and edited by E. Allison Peers, Burns \& Oates, 2002. ProQuest Ebook Central.

Saint Teresa of Avila. The Complete Works of St. Teresa of Avila: Vol. 3. Translated and edited by E. Allison Peers, Burns \& Oates, 2002. ProQuest Ebook Central.

Santa Teresa de Ávila. Escritos de Santa Teresa, añadidos é ilustrados por don Vicente de la Fuente, tomo I, Madrid, M. Rivadeneyra, 1861.

Shachar, Hila. "Authorial Histories: The Historical Film and the Literary Biopic." A Companion to the Historical Film, edited by Robert A. Rosenstone and Constantin Parvulescu, Wiley-Blackwell, 2013, pp. 199-218.

Shachar, Hila. Screening the Author: The Literary Biopic. Palgrave Macmillan, 2019.

Smith, Greg M. Film Structure and the Emotion System. Cambridge UP, 2003. 
Teresa, el cuerpo de Cristo [Theresa, the body of Christ], directed by Ray Loriga, performances by Paz Vega, Leonor Watling, and Geraldine Chaplin, S.A.V., 2007.

“Theresa: The Body of Christ (2007)." Box Office Mojo, http://www.boxofficemojo. com/title/tt0458500/?ref =bo tt ti Accessed 1 Aug. 2020.

“Theresa: The Body of Christ (2007)." IMDb, http://www.imdb.com/title/tt0458500/ Accessed 1 Aug. 2020.

Waddington, Andrucha. "Andrucha Waddington escribe sobre la experiencia de dirigir Lope." Noticine.com, http://noticine.com/iberoamerica/36-iberoamerica/11495andrucha-waddington-escribe-sobre-la-experiencia-de-dirigir-qlopeq.html Accessed 3 Aug. 2020.

Wheeler, Duncan. “Back to the Future: Repackaging Spain's Troublesome Past for Local and Global Audiences." (Re)viewing Creative, Critical and Commercial Practices in Contemporary Spanish Cinema, edited by Duncan Wheeler and Fernando Canet, Intellect, 2014, pp. 205-233. 